\title{
Sudden loss of ventilation through a double lumen endotracheal tube requiring emergency provision of a surgical airway by bronchotomy
}

\author{
Robert Torrance ${ }^{1 *}$, Alan Dawson ${ }^{2}$, Jared M Wohlgemut ${ }^{1}$, Keith Buchan² \\ From 23rd World Congress of the World Society of Cardio-Thoracic Surgeons \\ Split, Croatia. 12-15 September 2013
}

\begin{abstract}
A left completion pneumonectomy operation for primary lung cancer (left lower lobectomy) was complicated by sudden loss of ability to ventilate the patient via the double lumen endotracheal tube. The problem could not be overcome by the anesthesiologist. In the face of impending cardiorespiratory arrest a single lumen tube was introduced through an incision in the left main bronchus through to the right main bronchus. This lifesaving manoeuvre safeguarded the airway and permitted a successful outcome to the operation.
\end{abstract}

\section{Authors' details}

${ }^{1}$ School of Medicine and Dentistry, University of Aberdeen, Aberdeen, UK.

2Department of Cardiothoracic Surgery, Aberdeen Royal Infirmary, Aberdeen, UK.

Published: 11 September 2013
Cite this article as: Torrance et al: Sudden loss of ventilation through a
Colition double lumen endotracheal tube requiring emergency provision of a surgical airway by bronchotomy. Journal of Cardiothoracic Surgery 20138 (Suppl 1):P138.
* Correspondence: r.torrance.10@aberdeen.ac.uk

${ }^{1}$ School of Medicine and Dentistry, University of Aberdeen, Aberdeen, UK Full list of author information is available at the end of the article
Submit your next manuscript to BioMed Central and take full advantage of:

- Convenient online submission

- Thorough peer review

- No space constraints or color figure charges

- Immediate publication on acceptance

- Inclusion in PubMed, CAS, Scopus and Google Scholar

- Research which is freely available for redistribution 